Http://cendekia.pusatbahasa.or.id; Email: cendekiaoslo@gmail.com Center of Language and Culture Studies, Surakarta, Indonesia

Wijaya, Mokhamad Erfan. 2017. Pembelajaran Bahasa Berbasis Kurikulum 2013 di PAUD Asparaga Malang. Cendekia (2017), 11(2): 249 262.

\title{
PEMBELAJARAN BAHASA BERBASIS KURIKULUM 2013 DI PAUD ASPARAGA MALANG
}

\author{
Erfan Mokhamad Wijaya \\ Program Pascasarjana, Universitas Negeri Malang \\ E-mail: erfanmowi@gmail.com
}

\begin{abstract}
This classroom-based observation qualitative study describes language learning process in the kindergarten level based on the 2013 Curriculum. This study took place in the Kindergarten of Asparaga Malang and assigned all pupils as the research subject. Data of this study were obtained form classroom interactions in the Asparaga school using observation and interview. This study revealed that the pupils in Asparaga interacted with friends and teachers in four languages: (1) Javanese language, (2) Indonesian, (3) the English language, and (4) Arabic. Learning a language was considered interesting using of various methods: teachers applied the storytelling and play to teach the languages, and multiple medias to support language learning process were also used in support to use the books, pictures, and tablets.
\end{abstract}

Keywords: kindergarten, language learning, the 2013 Curriculum.

Pendidikan Anak Usia Dini (PAUD) Asparaga berdiri pada tahun 2008 yang didirikan oleh ketua PKK (Pemberdayaan Kesejahteraan Keluarga) yaitu Ibu Hj. Ana Rosdiana, S.Si. Pertama kali didirikan, lokasi PAUD Asparaga terletak di garasi rumah Bunda Din (panggilan akrab Ibu Hj. Ana Rosdiana, S.Si.). Lokasi PAUD Asparaga sekarang terletak di jalan Joyo Tamansari 1 RT.05 RW.06 Kecamatan Lowokwaru Kota Malang (warga biasa menyebut Balai RW). Perpindahan lokasi tersebut dimulai dari pertengahan tahun 2013 dan bertahan sampai sekarang. Sekilas, jika dilihat dari luar orang tidak akan tahu kalau di Balai RW terdapat sebuah sekolah karena letaknya yang tersembunyi. Di dekat sekolah tersebut terdapat sebuah sungai yang cukup besar dan juga ada jembatan yang menghubungkan jalan raya ke sekolah.

Di pagar sekolah terdapat papan nama yang bertuliskan "Posyandu Asparaga" dan sebuah banner bertuliskan "Pos PAUD Asparaga" yang tepat berada di atas pintu masuk ruang kelas. Selain itu, ditembok terdapat gambar pemandangan indah bernuansa anak-anak dan dipadukan dengan tanaman toga yang ditanam di botol bekas air mineral serta dicat menggunakan warna-warna cerah, ada juga kursi panjang dan dua ayunan yang sering digunakan wali murid untuk kegiatan BKB (Bina Keluarga Balita) seperti membuat menu makanan sehat, keterampilan untuk anak, penyuluhan tumbuh kembang anak, dan lain sebagainya.

Di bagian dalam sekolah terdapat tiga ruang kelas. Di setiap ruang kelas terdapat tulisan-tulisan dan gambar-gambar menarik dengan warna-warna cerah beserta berbagai macam mainan yang digunakan untuk menunjang pembelajaran. Menariknya, di antara 
3 ruang kelas ini terdapat sebuah wastafel dan sabun. Kemudian di bagian belakang juga terdapat sebuah kamar mandi dan dapur yang sangat bersih.

Sekolah yang mempunyai visi "Terwujudnya anak bangsa sehat, cerdas, ceria dan berakhlak mulia" dan misi "Membina anak bangsa yang beriman dan bertaqwa, Meningkatkan kesehatan jasmani dan rohani melalui pendidikan olahraga dan kesehatan, Meningkatkan bakat dan minat yang dimiliki oleh anak melalui pembelajaran interaktif, kreatif, dan inovatif" ini dari tahun ke tahun mengalami perombakan mulai dari lokasi untuk pembelajaran sampai dengan pergantian guru. Guru yang masih bertahan dari tahun 2008 sampai sekarang adalah Ibu Marlinda (bunda Linda). Kemudian di tahun 2010 ditambah 3 guru lagi yaitu (1) Ibu Nur Diana, S.Pd. (bunda Nur), (2) Ibu Dk Alifianur Zulfa, S.S, (bunda Alif), dan (3) Ibu Qurotul A'yuni, S.Pd. (bunda Yuni) yang sekaligus menjabat sebagai kepala sekolah PAUD Asparaga dari tahun 2010 sampai sekarang.

PAUD Asparaga juga sudah terdaftar di Dapodik (Data Pokok Pendidikan). Dapodik adalah suatu sistem pendataan dan pengelolaan data-data pendidikan yang bersifat mikro secara online dan real time. Dengan sistem ini maka pengelolaan riwayat data sekolah, siswa, guru/karyawan lebih mudah diterintegrasikan dan disimpan secara terpusat dan dapat diakses dengan lebih mudah dan terbuka oleh masyarakat dalam batasan tertentu melalui internet (Mustafa, Priowirjanto et al, 2008).

Kurikulum yang digunakan di sekolah ini adalah kurikulum 2013 Pendidikan Anak Usia Dini. Pemberlakuan kurikulum 2013 Pendidikan Anak Usia Dini ini sudah didukung dengan berbagai panduan dan strategi pembelajaran saintifik kurikulum 2013. Kurikulum 2013 ini perlu dilakukan karena sebagai dasar untuk anak agar dapat mencapai pendidikan yang lebih tinggi lagi. Sesuai dengan Permendikbud No 160 tahun 2014 tentang pemberlakuan kurikulum 2013 pasal 7 menjelaskan bahwa dengan diterapkannya kurikulum 2013 Pendidikan Anak Usia Dini diharapkan menjadi fundamental penyiapan peserta didik menjadi lebih siap dalam memasuki jenjang pendidikan yang lebih tinggi. Jadi, kurikulum 2013 Pendidikan Anak Usia Dini ini wajib dilaksanakan oleh satuan pendidikan sekolah dasar. Dengan menggunakan kurikulum 2013 pembelajaran di PAUD akan terprogram dengan baik. Pembelajaran di PAUD Asparaga juga menyenangkan, yaitu belajar sambil bermain. Kesenangan yang diperoleh melalui bermain memungkinkan anak belajar tanpa terpaksa dan tekanan sehingga disamping dapat berkembangnya motorik kasar maupun motorik halus juga dapat dikembangkan berbagai kecerdasan yang lain secara optimal. Hal ini sesuai dengan permendikbud nomor 146 tahun 2014 yang menjelaskan bahwa pembelajaran di PAUD harus menyenangkan, yaitu melalui bermain.

Kurikulum 2013 PAUD menjelaskan bahwa struktur PAUD memuat programprogram pengembangan yang mencakup: (1) nilai agama dan moral, (2) fisik motorik, (3) kognitif, (4) bahasa, (5) sosial emosional, dan (6) seni. Salah satu program yang perlu dikembangkan adalah bahasa. Kemampuan berbahasa pada anak usia dini harus dikembangkan seoptimal mungkin. Syakir Abdul Azhim (2011:37) menjelaskan bahwa pengenalan bahasa yang lebih dini dibutuhkan untuk memperoleh keterampilan bahasa yang baik. Pembelajaran bahasa di PAUD Aparaga menggunakan 4 bahasa, yaitu (1) bahasa Daerah (Jawa), (2) bahasa Indonesia, (3) bahasa Inggris, dan (4) bahasa Arab. 
Fokus penelitian mengandung penjelasan mengenai apa yang menjadi pusat perhatian serta kelak dibahas secara mendalam dan tuntas. Sugiyono (2010:285), berpendapat bahwa dalam pandangan penelitian kualitatif, gejala itu bersifat holistik (menyeluruh, tidak dapat dipisah-pisahkan), sehingga peneliti kualitatif tidak akan menetapkan penelitiannya hanya berdasarkan variabel penelitian, tetapi keseluruhan situasi sosial yang diteliti yang meliputi aspek tempat, pelaku, dan aktivitas yang berinteraksi secara sinergis. Dalam penelitian ini yang menjadi fokus penelitian adalah pembelajaran bahasa di PAUD Asparaga Malang. Fokus ini diambil karena untuk mengetahui bagaimana pembelajaran bahasa di PAUD Asparaga Malang berlangsung. Dari latar belakang dan fokus penelitian yang dikemukakan sebelumnya, penelitian ini akan mengungkap hal-hal yang terkait dengan pertanyaan: (1) Bagaimana pembelajaran di PAUD Asparaga Malang berlangsung?, dan (2) Bagaimana pembelajaran bahasa di PAUD Asparaga Malang?

Pembelajaran untuk anak usia dini bukan berarti anak harus disekolahkan pada umur yang belum seharusnya, dipaksa untuk mengikuti pelajaran yang akhirnya justru membuat anak menjadi terbebani dalam mencapai tugas perkembangannya. Pembelajaran untuk anak usia dini pada dasarnya adalah pembelajaran yang kita berikan pada anak agar anak dapat berkembang secara wajar. Permendikbud nomor 146 tahun 2014 menjelaskan bahwa Pendidikan Anak Usia Dini merupakan suatu upaya pembinaan yang ditujukan kepada anak sejak lahir sampai dengan usia 6 (enam) tahun yang dilakukan melalui pemberian rangsangan pendidikan untuk membantu pertumbuhan dan perkembangan jasmani dan rohani agar anak memiliki kesiapan dalam memasuki pendidikan lebih lanjut.

Pada hakikatnya anak belajar sambil bermain, oleh karena itu pembelajaran pada anak usia dini pada dasarnya adalah bermain. Greeberg (Isjoni, 2006) menyatakan bahwa pembelajaran dapat efektif jika anak dapat belajar melalui bekerja, bermain dan hidup bersama dengan lingkungannya. Sesuai dengan karakteristik anak usia dini yang bersifat aktif dalam melakukan berbagai ekplorasi terhadap lingkungannya, maka aktivitas bermain merupakan bagian dari proses pembelajaran. Untuk itu pembelajaran pada usia dini harus dirancang agar anak merasa tidak terbebani dalam mencapai tugas perkembangannya. Proses pembelajaran yang dilakukan harus berangkat dari yang dimiliki anak. Setiap anak membawa seluruh pengetahuan yang dimilikinya terhadap pengalaman-pengalaman baru.

Fuad Hasan (1998) menjelaskan bahwa aktivitas bermain juga berefek pada perkembangan jasmani anak, karena melalui bermain juga tersalurkan berbagai dorongan dari anak untuk melakukan gerakan-gerakan tertentu. Hal lain yang terpenting dalam menilai perilaku anak adalah bahwa selama berada dalam situasi bermain, kemampuan anak bukan dilihat bagaimana tingkat prestasinya, melainkan sejauh mana anak menghayati kepuasannya. Dalam situasi ini anak tidak merasa dituntut untuk menampilkan kinerja bagi tercapainya suatu prestasi tertentu. Oleh karena itu situasi bermain hendaknya dapat membangkitkan perasaan yang menyenangkan.

Pembelajaran anak usia dini tidak lepas dari pembelajaran bahasanya. Syakir Abdul Azhim (2011:37) menjelaskan bahwa pengenalan bahasa yang lebih dini 
dibutuhkan untuk memperoleh keterampilan bahasa yang baik. Perkembangan bahasa dipengaruhi oleh 5 faktor, yaitu: intelegensi, status sosial, jenis kelamin, hubungan keluarga, dan kedwibahasaan (Pemakaian dua bahasa). Fungsi bahasa bagi anak usia dini adalah untuk mengembangkan kemampuan intelektual dan kemampuan dasar anak. Berikut adalah beberapa fungsi bahasa bagi anak usia dini menurut Depdiknas.

1. Sebagai alat untuk berkomunikasi dengan lingkungan

2. Sebagai alat untuk mengembangkan kemampuan intelektual anak

3. Sebagai alat untuk mengembangkan ekspresi anak

4. Sebagai alat untuk menyatakan perasaan dan buah pikiran kepada orang lain

Selanjutnya Depdiknas juga menjelaskan beberapa aspek yang berkaitan dengan perkembangan bahasa anak usia dini antara lain:

1. Kosa kata

Seiring dengan perkembangan anak dan pengalamannya berinteraksi dengan lingkungannya, kosa kata anak berkembang dengan pesat.

2. Sintaksis (tata bahasa)

Walaupun anak belum mempelajari tata bahasa, akan tetapi melalui contoh-contoh berbahasa yang di dengar dan dilihat anak di lingkungannya, anak telah dapat menggunakan bahasa lisan dengan susunana kalimat yang baik.

3. Semantik

Semantik maksudnya penggunaan kata sesuai dengan tujuannya. Anak di PAUD sudah dapat mengekspresikan keinginan, penolakan dan pendapatnya dengan menggunakan kata-kata dan kalimat yang tepat.

4. Fonem (satuan bunyi terkecil yang membedakan kata)

Anak di PAUD sudah memiliki kemampuan untuk merangkaikan bunyi yang di dengarnya menjadi satu kata yang mengandung arti. Misalnya: i.b.u menjadi ibu.

Penggunaan metode dalam pembelajaran bahasa untuk anak usia dini juga sangat penting. Penggunaan metode pengajaran yang tepat dan sesuai dengan karakter anak akan dapat memfasilitasi perkembangan berbagai potensi dan kemampuan anak secara optimal serta tumbuhnya sikap dan perilaku positif bagi anak. Depdiknas (2004) menjelaskan bahwa secara teknik ada beberapa metode yang tepat untuk diterapkan pada anak usia dini, yaitu (1) metode bercerita, (2) metode bercakap-cakap, (3) metode tanya jawab, (4) metode karyawisata, (5) metode demonstrasi, (6) metode sosiodrama, (7) metode eksperimen (8) metode proyek, dan (9) metode pemberian tugas. Menurut Moeslihatoen (2004:157) salah satu metode yang efektis adalah metode bercerita. Bercerita sebagai sarana efektif untuk memberikan nilai-nilai kepada anak tanpa mereka merasa dinasehati secara langsung. Cerita yang berkesan akan tetap tersimpan di memori sang anak sampai dia dewasa kelak.

\section{METODE}

\section{Pendekatan}

Pendekatan yang digunakan dalam penelitian ini adalah pendekatan kualitatif. Menurut pendapat Moleong (2009:4), penelitian kualitatif merupakan penelitian yang 
menghasilkan data deskriptif berupa kata-kata tertulis atau lisan dari orang-orang dan perilaku yang dapat diamati. Penelitian ini menggunakan pendekatan kualitatif dengan tujuan untuk memperoleh gambaran yang komprehensif dan mendalam tentang bagaimana pembelajaran bahasa di PAUD Asparaga Malang.

Jenis penelitiannya merupakan penelitian deskriptif, yaitu penelitian yang bersifat alamiah, yang menggambarkan setiap kejadian yang terjadi pada saat setiap tahapan penelitian berlangsung (Arikunto, 2010:3). Pada penelitian ini peneliti mendeskripsikan semua kejadian yang terjadi secara alami yang terjadi pada saat proses pembelajaran di PAUD Asparaga Malang.

\section{Informan}

Di dalam penelitian kualitatif, pemberi informasi disebut sebagai informan. Pemilihan informan ini didasarkan pada subyek yang menguasai permasalahan, memiliki data, dan bersedia memberikan data yang benar-benar relevan dan kompeten dengan permasalahan yang diteliti. Informan dalam penelitian ini adalah:

1. Guru yang mengetahui awal berdirinya PAUD Asparaga Malang

2. Kepala sekolah PAUD Asparaga Malang

\section{Teknik Pengumpulan Data}

Data dikumpulkan dengan menggunakan metode observasi partisipatif, wawancara, dokumentasi. Observasi digunakan sebagai salah satu cara pengumpulan data apabila penelitian yang dilakukan berhubungan dengan perilaku manusia, proses kerja, dan responden yang diamati jumlahnya tidak terlalu besar (Sugiyono, 2010:203). Kegiatan observasi ini dilakukan untuk melihat aktivitas yang dilakukan siswa dan guru selama proses belajar mengajar berlangsung. Wawancara dilakukan beberapa kali dan semakin mendalam. Dalam hal ini peneliti membangun kepercayaan dengan cara terus bertemu, menyapa, dan bercakap-cakap dengan informan agar informan bersedia mengungkapkan secara menyeluruh tentang pembelajaran. Dokumentasi dilakukan untuk melengkapi data-data yang telah diperoleh melalui observasi ataupun wawancara. Data dokumentasi pada penelitian ini adalah hasil foto dan rekaman video. Observasi, wawancara, dan dokumentasi dilakukan mulai tanggal 28 Maret 2016 s/d 15 April 2016.

\section{Teknik Analisis Data}

Sugiyono (2010:334) menyatakan bahwa "Analisis data adalah proses mencari dan menyusun secara sistematis data yang diperoleh dari hasil wawancara, catatan lapangan, dan bahan-bahan lain sehingga mudah dipahami, dan temuannya dapat diinformasikan kepada orang lain. Analisis data dalam penelitian ini adalah menggunakan analisis interaktif milik Miles dan Huberman (1984) yaitu terdiri dari pengumpulan data, reduksi data, penyajian data dan kesimpulan. Pengumpulan data dilakukan dengan cara mengumpulkan catatan observasi, catatan hasil wawancara, dan studi dokumentasi.

Reduksi data adalah bagian dari bagian dari proses analisis yang mempertegas, memperpendek, membuat fokus, membuang hal-hal yang tidak penting dan mengatur data sedemikian rupa sehingga simpulan penelitian dapat dilakukan. Pada tahap ini, 
proses pengumpulan data telah selesai dilakukan dan semua hasil catatan lapangan dibaca, dipahami, dan dibuat ringkasan. Ringkasan berisi tentang uraian hasil penelitian terhadap catatan lapangan, fokus dan jawaban terhadap masalah yang diteliti.

Dalam penelitian kualitatif, penyajian data bisa dilakukan dalam bentuk uraian singkat, bagan, hubungan antar kategori, flowchart, dan sejenisnya. Dengan penyajian data maka akan memudahkan untuk memahami apa yang terjadi, merencanakan kerja selanjutnya berdasarkan apa yang telah dipahami tersebut (Sugiyono, 2010:341). Penyajian data dalam penelitian ini yaitu dengan melakukan pengorganisasian data dalam bentuk penyajian data informasi berupa teks naratif yang memungkinkan untuk menarik kesimpulan dan pengambilan tindakan. Data yang didapat dari observasi, wawancara, dan dokumentasi.

Terakhir adalah kesimpulan, Miles dan Huberman dalam Sugiyono (2010:345) menyatakan bahwa kesimpulan awal yang dikemukakan masih bersifat sementara, dan akan berubah bila tidak diemukan bukti-bukti yang kuat yang mendukung pada tahap pengumpulan data berikutnya. Tetapi apabila kesimpulan yang dikemukakan pada tahap awal, didukung oleh bukti-bukti yang valid dan konsisten saat peneliti kembali ke lapangan mengumpulkan data, maka kesimpulan yang dikemukakan merupakan kesimpulan yang kredibel. Pada tahap ini, data yang diperoleh peneliti mengenai pembelajaran bahasa yang yang telah didapat peneliti diproses dan dianalisis agar menjadi data yang dapat dirangkum dan selanjutnya menjadi suatu kesimpulan.

\section{Kualitas Keabsahan Penelitian}

Pada penelitian kualitatif, terdapat beberapa kriteria untuk menetapkan keabsahan data, meliputi derajat kepercayaan (credibility), keteralihan (transferability), keberuntungan (dependability), dan kepastian (confirmability). Kriteria keabsahan data yang digunakan dalam penelitian ini adalah kriteria derajat kepercayaan (credibility).

Derajat kepercayaan yang digunakan dalam penelitian ini adalah triangulasi. Sugiyono (2010:373) menjelaskan bahwa triangulasi merupakan cara yang digunakan untuk mengecek data dengan menggabungkan berbagai teknik pengumpulan data dan sumber data yang sudah ada. Dalam penelitian ini, dilakukan tringulasi sumber, yaitu pengecekan data yang dilakukan dari beberapa sumber yang telah diperoleh, yaitu dalam hasil observasi, wawancara, dan dokumentasi. Berdasarkan triangulasi sumber tersebut, peneliti melakukan pengecekan data yang diperoleh dari observasi, wawancara dan dokumentasi.

\section{HASIL DAN BAHASAN \\ Deskripsi Umum PAUD Asparaga}

Jumlah siswa PAUD Aspara Malang tahun pelajaran 2015-2016 seluruhnya adalah 48 siswa. 48 siswa ini dibagi ke dalam kelas sesuai tingkatan usia, yaitu (1) kelas usia 2-3 ,tahun 18 siswa, (2) kelas usia 3-4 tahun 12 siswa, dan (3) kelas usia 4-5 tahun 18 siswa. Di PAUD Asparaga siswa masuk pukul 08.00 WIB dan pulang pukul 10.30 WIB. Untuk guru harus hadir lebih awal sekitar pukul 07.00 pagi karena akan diadakan rapat dan koordinasi sebelum pembelajaran dimulai. Pembelajaran di PAUD Asparaga hanya tiga (3) kali dalam satu minggu yaitu hari senin, rabu, dan jumat. Setiap hari 
senin diadakan upacara bendera bersama, hari rabu dan jumat semua siswa mengikuti senam pagi sebelum masuk ke dalam kelas. Setiap kali akan masuk kelas siswa diminta baris terlebih dahulu dan berdoa, kemudian didampingi guru kelas masuk menuju kelas masing-masing. Di dalam kelas tidak lupa guru mengajak siswa berdoa bersama kembali sebelum pembelajaran dimulai. Pembelajaran di PAUD Asparaga siswa lebih banyak belajar sambil bermain. Hal ini sesuai dengan pendapat Greeberg (Isjoni, 2006) yang menyatakan bahwa pembelajaran dapat efektif jika anak dapat belajar melalui bekerja, bermain dan hidup bersama dengan lingkungannya.

Secara umum, pembelajaran di PAUD Asparaga ini berjalan lancar dan mengikuti langkah-langkah yang ada dalam rencana pembelajaran yang sebelumnya sudah dipersiapkan dan disusun oleh tim guru setiap minggu. Di dalam rencana pembelajaran berisi tema, konsep dan kosakata, kegiatan, bahan dan alat. Langkahlangkah yang dimulai dengan kegiatan awal (berdoa, salam, absen), kegiatan inti (belajar sesuai tema dan RKH/Rencana Kegiatan Harian), dan kegiatan penutup (refleksi, evaluasi, berdoa) terlaksana dengan sangat baik dan lancar.

Pukul 10.00 WIB seluruh siswa istirahat dan makan snack bersama. Sebelum makan bersama, siswa diminta untuk berbaris dengan tertib dan mencuci tangan terlebih dahulu. Ternyata inilah alasan kenapa ada wastafel di antara ruang kelas tersebut. Berikut merupakan foto yang menunjukkan siswa berbaris dengan tertib saat mencuci tangan.

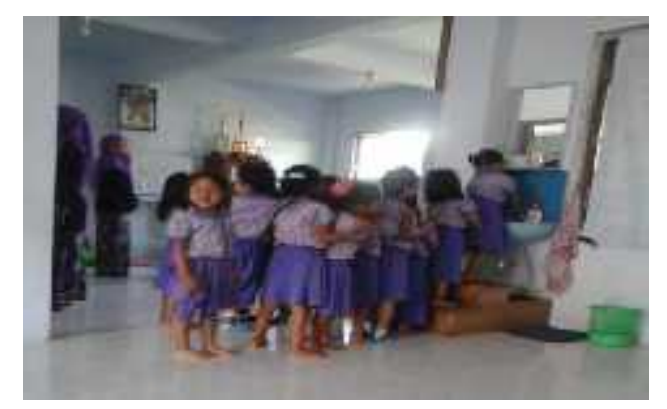

\section{Gambar 1 Siswa terlihat tertib saat mencuci tangan}

Uniknya, untuk snack bukan siswa yang membawa bekal sendiri dari rumah, melainkan snack disediakan oleh wali murid yang piket pada hari tersebut. Berdasarkan hasil wawancara dengan kepala sekolah, untuk snack memang yang menyiapkan wali murid, tetapi uang yang digunakan untuk membuat atau membeli snack tersebut adalah hasil dari iuran bersama setiap bulan. Untuk menu ditentukan oleh guru agar wali murid tidak serta merta memberikan makanan yang tidak sehat untuk siswa. Makanan yang biasa di berikan untuk siswa antara lain: kue tradisional (nagasari, roti kukus, lemper), buah (melon, jeruk, pisang), bubur kacang hijau, sup dan mie buatan sendiri tanpa menggunakan MSG. Setelah selesai makan bersama sekitar pukul 10.30 WIB seluruh siswa kembali ke kelas masing-masing untuk refleksi dan evaluasi bersama dilanjutkan dengan berdoa sebelum pulang ke rumah.

Pembelajaran di sekolah ini tidak hanya interaksi antara guru dan siswa seperti belajar bahasa, berhitung, bernyanyi, dan menari. Pembelajaran di sekolah ini juga lebih 
menekankan kepada pembiasaan-pembiasaan seperti upacara bendera yang dilaksanakan setiap hari senin untuk membangun rasa nasionalisme siswa sejak dini, berbaris dengan rapi sebelum masuk kelas, mencuci tangan sebelum makan, berdoa bersama sebelum memulai pelajaran, berdoa sebelum dan sesudah makan, serta berdoa setelah selesai pembelajaran. Kebiasaan-kebiasaan tersebut juga termasuk pembelajaran untuk anak usia dini yang perlu diperhatikan. Kemudian khusus pada hari jumat sekitar pukul 10.30 - 11.30 juga ada kegiatan ekstrakulikuler seperti bahasa Inggris, bahasa Arab, dan menari.

\section{Pembelajaran Bahasa di PAUD Asparaga}

Pembelajaran bahasa di PAUD Asparaga Malang tidak lepas dari kurikulum 2013. Pengajar hanya sebagai fasilitator dalam kegiatan belajar mengajar. Meskipun peserta didik masih sangat kecil tetapi mereka diharapkan dan diusahakan untuk dapat belajar mandiri. Seperti pembelajaran yang sudah dilakukan di sekolah PAUD Asparaga Malang. Pembelajaran bahasa di PAUD Asparaga ini siswa lebih ditekankan dalam keterampilan berbicara terlebih dahulu daripada keterampilan yang lain. Hal ini disebabkan karena dalam segi bahasa siswa masih belum muncul. Seperti yang diceritakan oleh Bunda Yuni selaku kepala sekolah PAUD Asparaga Malang, sebagai berikut.

"Karena kemampuan dari segi bahasa itu mereka belum muncul jadi kami dril untuk bahasanya dulu, keberaniannya dulu, untuk masalah keterampilan menulisnya itu yang nomor sekian, tetapi keberanian untuk berbicara, keberanian untuk mengungkapkan sesuatu itu yang utama dulu."

Nurhadi (1995:342) mengemukakan bahwa berbicara berarti mengemukakan ide atau pesan lisan secara aktif. Peserta didik belajar berbicara melalui interaksi dengan lingkungannya. Selain itu, lingkungan memberikan pelajaran terhadap tingkah laku, ekspresi dan penambahan pembendaharaan kata. Hal yang serupa juga dikemukakan oleh Tim pengembang ilmu pendidikan (2007:125) dalam pembelajaran berbicara yang paling penting adalah mengajarkan keterampilan berkomunikasi lisan dengan orang lain. Jadi, keterampilan berbicara sebaiknya diajarkan terlebih dahulu dalam pembelajaran, terutama dalam mempelajari sebuah bahasa baru.

Pembelajaran bahasa di PAUD Asparaga ini menggunakan 4 bahasa, yaitu (1) bahasa Daerah (Jawa), (2) bahasa Indonesia, (3) bahasa Inggris, dan (4) bahasa Arab. Hal ini seperti yang dikatakan oleh Bunda Linda selaku guru terlama di PAUD Asparaga Malang, sebagai berikut.

"Di Paud Asparaga ada 4 bahasa, ada Jawa, Indonesia,Inggris, Arab dan di agendakan akan ada bahasa Mandarin, tapi masih belum ada gurunya."

Pembelajaran bahasa yang menarik juga tidak lepas dari penggunaan berbagai macam metode. Metode yang digunakan di PAUD Asparaga adalah metode bercerita. Seperti yang dikatakan oleh Bunda Yuni, sebagai berikut. 
"Siswa diminta satu-satu untuk bercerita biar tidak malu berbicara dan bisa mengungkapkan sesuatu."

Selain metode bercerita, juga menggunakan metode bermain peran.

"Misalkan temanya jual beli biasanya kita memakai metode bermain peran dengan tema jual beli, jadi disesuaikan dengan tema."

Malik Jamaluddin (2005:68) menyatakan bahwa dalam metode bermain peran peserta diminta untuk melakukan peran tertentu dan menyajikan "permainan peran" dan melakukan "dialog-dialog" tertentu yang menekankan pada karakter, sifat atau sikap yang perlu dianalisa. Bermain peran haruslah mengungkapkan suatu masalah atau kondisi nyata yang akan dipergunakan bahan diskusi atau pembahasan materi tertentu. Dalam metode bermain peran, peserta didik diperlakukan sebagai subyek pembelajaran, secara aktif melakukan praktik-praktik berbahasa bersama teman-temannya pada situasi tertentu. Belajar efektif dimulai dari lingkungan yang berpusat pada diri peserta didik. Seperti yang dilakukan di PAUD Asparaga Malang dengan materi jual beli. Jadi, ada peserta didik yang menjadi penjual dan menjadi pembeli. Dapat disimpulkan bahwa metode pembelajaran bermain peran adalah salah satu cara yang cukup ampuh digunakan dalam proses pembelajaran.

Selain metode, media juga penting dalam pembelajaran. Di PAUD Asparaga menggunakan beberapa media dalam pembelajaran bahasanya. Media yang digunakan antara lain: buku, gambar, dan tablet. Seperti yang diceritakan oleh Bunda Yuni berikut ini.

"Kami untuk media sesuai dengan rencana, misalkan tema bercerita, berarti bisa menggunakan media buku, gambar, atau misalnya nanti bermain peran, ada juga yang memakai tablet."

Berikut merupakan salah satu foto media buku yang digunakan dalam metode bercerita. 


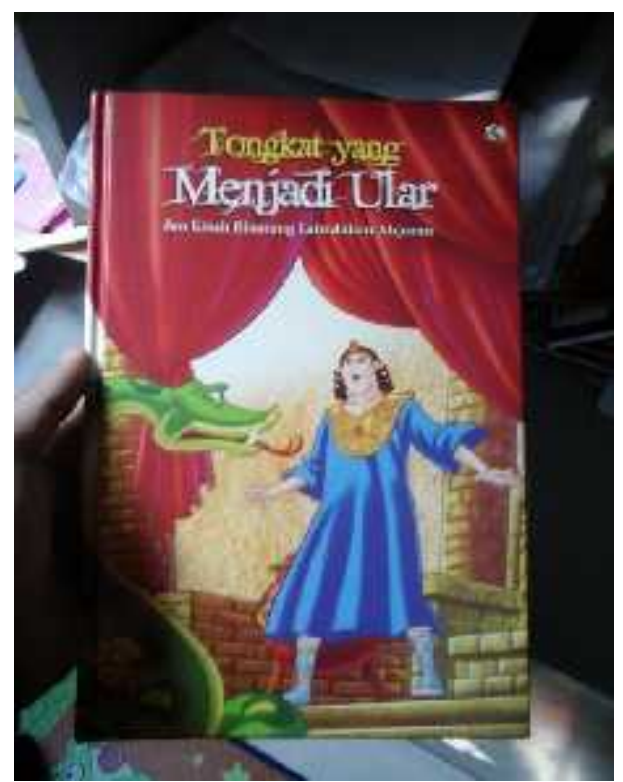

Gambar 2. Buku cerita Nabi

Untuk pembelajaran bahasa asing seperti bahasa Inggris dan bahasa Arab dalam pelaksanaannya hanya sebatas menggunakan lagu dalam pembelajarannya. Dengan bernyanyi siswa akan lebih aktif dan lebih cepat memahami bahasa yang dipelajari. Hal ini seperti yang diceritakan oleh Bunda Yuni, sebagai berikut.

"Untuk pembelajaran bahasa asing hanya sebatas menggunakan lagu, warna, anggota tubuh, jadi belum jauh dan baru mulai, ya nanti penggennya setiap jumat itu bergantian ada ekstra bahasa Inggris, bahasa Arab kemudian ada menari, seperti itu."

Dari hasil penelitian ini ditemukan bahwa selain metode, media pembelajaran juga penting dalam menunjang pembelajaran bahasa. Dengan adanya media pembelajaran juga dapat mempermudah guru dalam proses belajar mengajar. Daryanto (2013:6) menyimpulkan bahwa media pembelajaran merupakan segala sesuatu yang dapat digunakan untuk menyalurkan pesan yang berupa bahan pembelajaran sehingga guru dapat merangsang perhatian, minat, pikiran, dan perasaan siswa dalam kegiatan belajar untuk mencapai tujuan belajar. Peran media sangat penting dalam proses pebelajaran karena adanya media dapat membantu siswa dalam mengolah informasi guna mencapai tujuan pembelajaran. Media pembelajaran juga mempunyai banyak manfaat seperti yang diungkapkan oleh Arsyad (2009:26) sebagai berikut.

a) Media pembelajaran dapat memperjelas pesan dan informasi sehingga dapat memperlancar proses pembelajaran.

b) Media pembelajaran dapat meningkatkan dan mengarahkan perhatian siswa sehingga dapat menimbulkan motivasi belajar, interaksi yang lebih langsung antara siswa dan lingkungannya, dan kemungkinan siswa untuk belajar secara mandiri sesuai dengan kemampuan dan minatnya. 
CENDEKIA, Vol. 11, No. 2, Oktober 2017

p ISSN: 1978 2098; e ISSN: 2407 8557

Http://cendekia.pusatbahasa.or.id; Email: cendekiaoslo@gmail.com Center of Language and Culture Studies, Surakarta, Indonesia

Wijaya, Mokhamad Erfan. 2017. Pembelajaran Bahasa Berbasis Kurikulum 2013 di PAUD Asparaga Malang. Cendekia (2017), 11(2): 249 262.

c) Media pembelajaran dapat mengatasi keterbatasan indera, ruang, dan waktu.

d) Media pembelajaran dapat memberikan kesamaan pengalaman kepada siswa tentang peristiwa-peristiwa di lingkungan mereka.

Dari hasil observasi ditemukan beberapa media yang menurut peneliti dapat digunakan dalam pembelajaran bahasa. Berikut merupakan foto media yang dapat digunakan dalam pembelajaran bahasa.

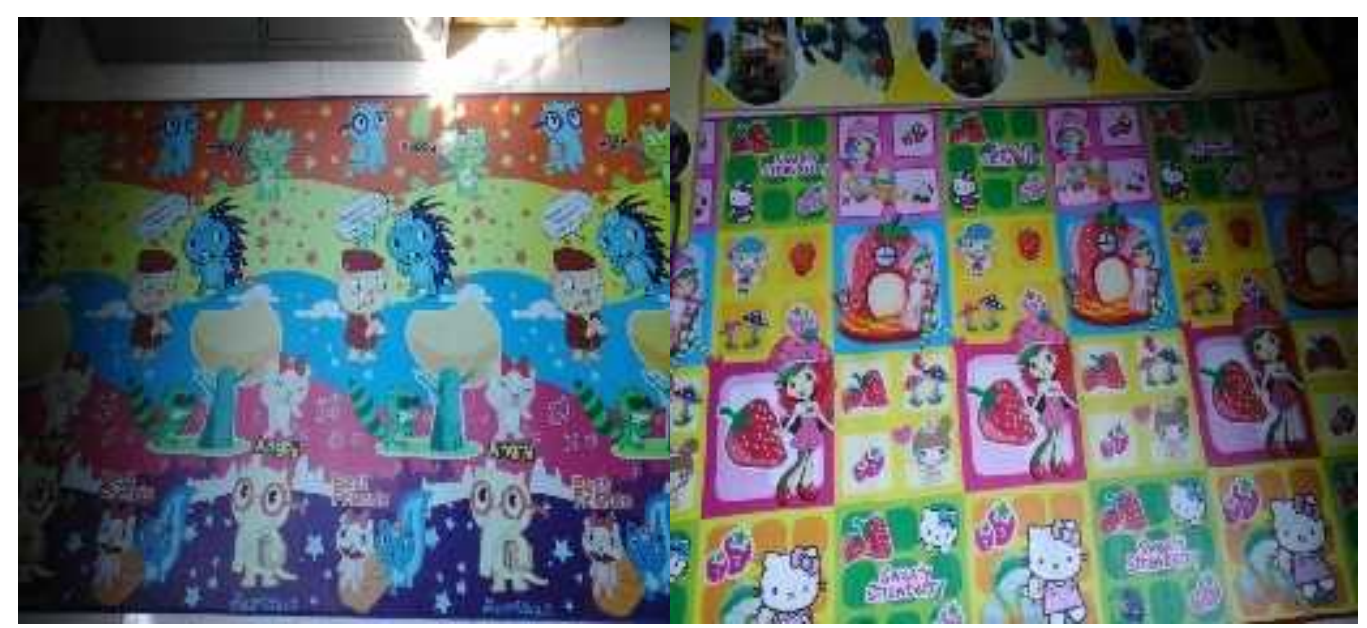

\section{Gambar 3. Tikar bertuliskan bahasa Inggris}

Tikar bertuliskan bahasa Inggris ini selain memiliki fungsi sebagai alas duduk juga dapat digunakan sebagai media pembelajaran karena tikar tersebut memiliki kosakata bahasa Inggris seperti sweet, strawberry, happy, angry, best dan friend. Selain tikar juga ada sebuah audio dan TV di dalam ruang kelas.

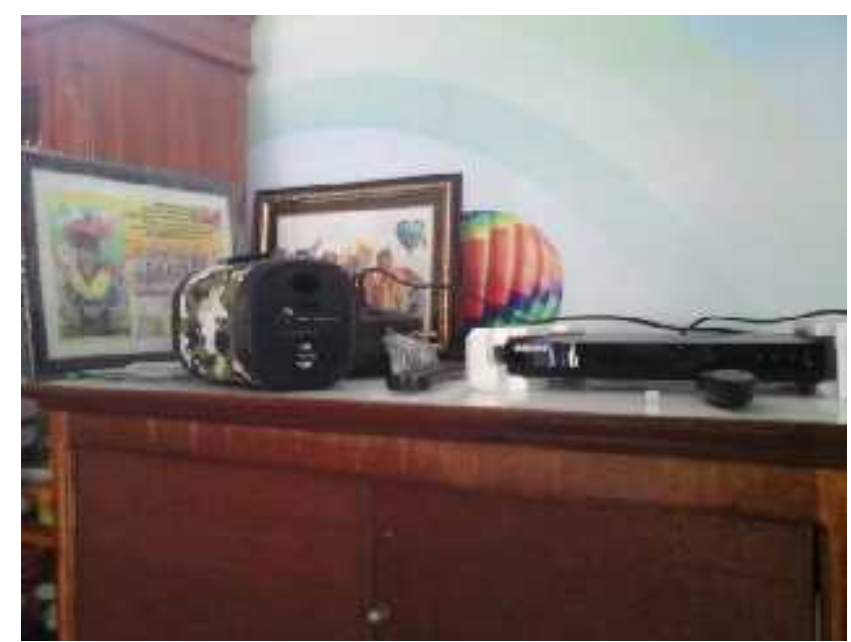

Gambar 4. Audio 


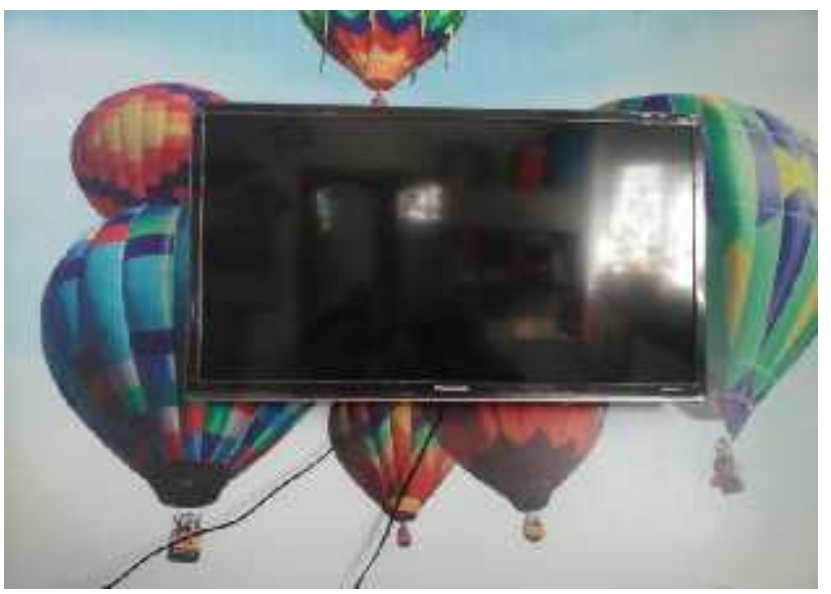

Gambar 5. TV

Menurut peneliti audio dan TV merupakan media yang juga dapat digunakan dalam pembelajaran bahasa. Audio bisa digunakan untuk mendengarkan lagu, kemudian siswa bisa ikut bernyanyi bersama-sama dengan guru. Alasan menggunakan lagu karena lagu merupakan bagian penting dari pembelajaran bahasa. Lagu dapat menjadikan para pembelajar lebih sensitif terhadap bunyi. Selain itu, lagu bisa menjadikan kelas lebih menarik dan semarak. Lagu juga mempresentasikan bahasa yang sudah dikenal pembelajar dalam bentuk yang baru dan menyenangkan. Lagu bisa dimanfaatkan untuk mengembangkan semua keterampilan bahasa secara integratif, termasuk meningkatkan kemampuan pronunciation pembelajar. Brown (2000) menyatakan bahwa ada salah satu prinsip pembelajaran, yaitu automaticity. Menurutnya, faktor yang cenderung menghambat kemunculan automaticity ini adalah terlalu berlebihan dalam menganalisa bahasa, berpikir terlalu banyak tentang forms (struktur/grammar) dan secara sadar mengingat-ingat aturan bahasa. Dalam hal ini lagu bisa membantu terjadinya automatic processing of language, yaitu peserta didik mengerjakan sebuah kegiatan belajar tanpa sengaja. Sedangkan TV bisa digunakan untuk menonton video yang terkait tema, misalnya ditayangkan sebuah video percakapan atau bermain peran terkait tema jual beli. Lagu dan video tentu harus sesuai dengan pembelajaran bahasa anak usia dini.

\section{SIMPULAN}

Pembelajaran untuk anak usia dini bukan berarti anak harus disekolahkan pada umur yang belum seharusnya, dipaksa untuk mengikuti pelajaran yang akhirnya justru membuat anak menjadi terbebani dalam mencapai tugas perkembangannya. Pembelajaran untuk anak usia dini harus menyenangkan seperti belajar sambil bermain. Dengan adanya kegiatan bermain, anak tidak akan merasa terbebani dalam belajar. Pembelajaran anak usia dini juga tidak lepas dari pembelajaran bahasanya. Pembelajaran bahasa penting dikembangkan karena pengenalan bahasa yang lebih dini dibutuhkan untuk memperoleh keterampilan bahasa yang baik untuk anak.

Penelitian ini menemukan beberapa hal tentang pembelajaran bahasa yang ada di PAUD Asparaga Malang. Untuk pembelajaran bahasa di PAUD Asparaga ini siswa lebih ditekankan dalam keterampilan berbicara terlebih dahulu daripada keterampilan 
yang lain. Hal ini disebabkan karena dalam segi bahasa siswa belum begitu muncul. Pembelajaran bahasa di PAUD Aparaga menggunakan 4 bahasa, yaitu (1) bahasa Daerah (Jawa), (2) bahasa Indonesia, (3) bahasa Inggris, dan (4) bahasa Arab.

Pembelajaran bahasa yang menarik juga tidak lepas dari penggunaan berbagai macam metode. Metode yang digunakan di PAUD Asparaga Malang adalah metode bercerita dan bermain. Selain metode, sekolah ini juga menggunakan beberapa media untuk mendukung proses pembelajaran bahasa. Media yang digunakan antara lain: buku, gambar, dan tablet. Untuk pembelajaran bahasa asing seperti bahasa Inggris dan bahasa Arab sebatas menggunakan lagu dalam pembelajarannya.

\section{DAFTAR RUJUKAN}

Arikunto, Suharsimi. 2010. ProsedurPenelitian: Suatu Pendekatan Praktik. Jakarta: PT Rineka Cipta.

Arsyad, Azar. 2009. Media Pembelajaran. Jakarta: Rajawali Pers.

Brown, D. (Nurhayati). 2000. Teaching by Principle. Majalah Ilmiah Pembelajaran nomor 1. Vol. 5 Mei 2009.

Daryanto. 2013. Media Pembelajaran: Perananya sangat penting dalam mencapai tujuan pembelajaran. Yogyakarta: Gava media.

Depdiknas. 2000. Kurikulum Berbasis Kompetensi TK. Jakarta: Dorektorat Jendral Pendidikan Dasar Menengah.

Depdiknas. 2004. Kurikulum TK dan RA. Jakarta: Depdiknas.

Fuad Hasan, 1998. Bermain Sebagai Anak. Makalah disajikan di seminar pendidikan anak usia dini. Universitas Negeri Yogyakarta.

Isjoni. 2006. Model Pembelajaran yang Efektif bagi Pendidikan Anak Usia Dini. www.isjoni.net/web/content/view/44/4/-44k-Tembolok-Laman. Pada tanggal 16 April 2016.

Malik, Jamaluddin. 2005. Pemberdayaan Pesantren Menuju Kemandirian dan Profesionalisme Santri dengan Metode Daurah Kebudayaan. Jakarta: Pustaka Pesantren.

Miles, M. B. \& Huberman, A. M. 1984. Qualitative Data Analysis: A Sourcebook of New Methods. California; SAGE publications Inc.

Moeslihatoen. 2004. Metode Pengajaran Di taman Kanak-kanak. Jakarta: PT. Asdi Mahasatya.

Moleong, Lexy, J. 2009. Metodologi Penelitian Kualitatif. Bandung: PT Remaja Rosdakarya.

Moll, Luis C. 1993. Vygotsky \& Educational Instructional Implications and Aplications of Sociohistorical Psychology. Australia: Cambridge University Press.

Mustafa, Khalid et al. 2008. Penerapan Sistem Pengelolaan Data Pokok Pendidikan (DAPODIK). Makalah disajikan pada e-Indonesia Initiative 2008-Konferensi dan Temu Nasional Teknologi Informasi dan Komunikasi untuk Indonesia. Jakarta.

Nurhadi, 1995. Tata Bahasa Pendidikan: Landasan Penyusunan Buku Pelajaran Bahasa. Semarang: IKIP Semarang Press. 
CENDEKIA, Vol. 11, No. 2, Oktober 2017

p ISSN: 1978 2098; e ISSN: 2407 8557

Http://cendekia.pusatbahasa.or.id; Email: cendekiaoslo@,gmail.com Center of Language and Culture Studies, Surakarta, Indonesia

Wijaya, Mokhamad Erfan. 2017. Pembelajaran Bahasa Berbasis Kurikulum 2013 di PAUD Asparaga Malang. Cendekia (2017), 11(2): 249 262.

Permendikbud. 2014. Kurikulum 2013 Pendidikan Usia Dini Nomor 146. Jakarta:

Menteri Pendidikan dan Kebudayaan Republik Indonesia.

Rusmawati, Nunung. 2009. Pelaksanaan Pembelajaran Pendekatan Beyond Centers and Circle Time (BCCT) di Pusat PAUD Firdaus International Preschool Banjarnegara. Tesis. Surakarta. Universitas Sebelas Maret.

Sugiyono. 2010. Metode Penelitian Kuantitatif, Kualitatif, dan R\&D. Bandung: CV Alfabeta.

Syakir Abdul Azhim. 2011. Membimbing Anak Terampil Berbahasa. Depok: Gema Insani Press.

Tim Pengembang Ilmu Pendidikan. 2007. Ilmu \& Aplikasi Pendidikan. Bandung: PT IMTIMA.

Wijayati, Primardiana H. 2011. Pedagang Angkringan di Bawah Fly Over Janti Yogyakarta. Laporan hasil penelitian. Yogyakarta: Universitas Negeri Yogyakarta 